\title{
Influence of Low pH Stress on Growth, Specific Biochemical Parameters and Antioxidants amongst Selected Nostoc Strains
}

\author{
Himani Priya ${ }^{1}$, Kumari Chanchala Priya $^{2}$, Neeraj Kumar ${ }^{3}$, \\ Ranjit Singh $^{4}$ and Dolly Wattal Dhar ${ }^{1}$
}

${ }^{1}$ Centre for Conservation and Utilisation of Blue Green Algae, Division of Microbiology,

ICAR-Indian Agricultural Research Institute, New Delhi-110012, India

${ }^{2}$ Division of Agricultural Engineering, ICAR-Indian Agricultural Research Institute, New Delhi-110012, India

${ }^{3}$ Department of Plant Breeding and Genetics, Dr RPCAU, Pusa, Bihar-848125, India

${ }^{4}$ Processing and Product Development Division, ICAR-Indian Institute of Natural Resins and

Gums, Namkum, Ranchi-834010, India

*Corresponding author

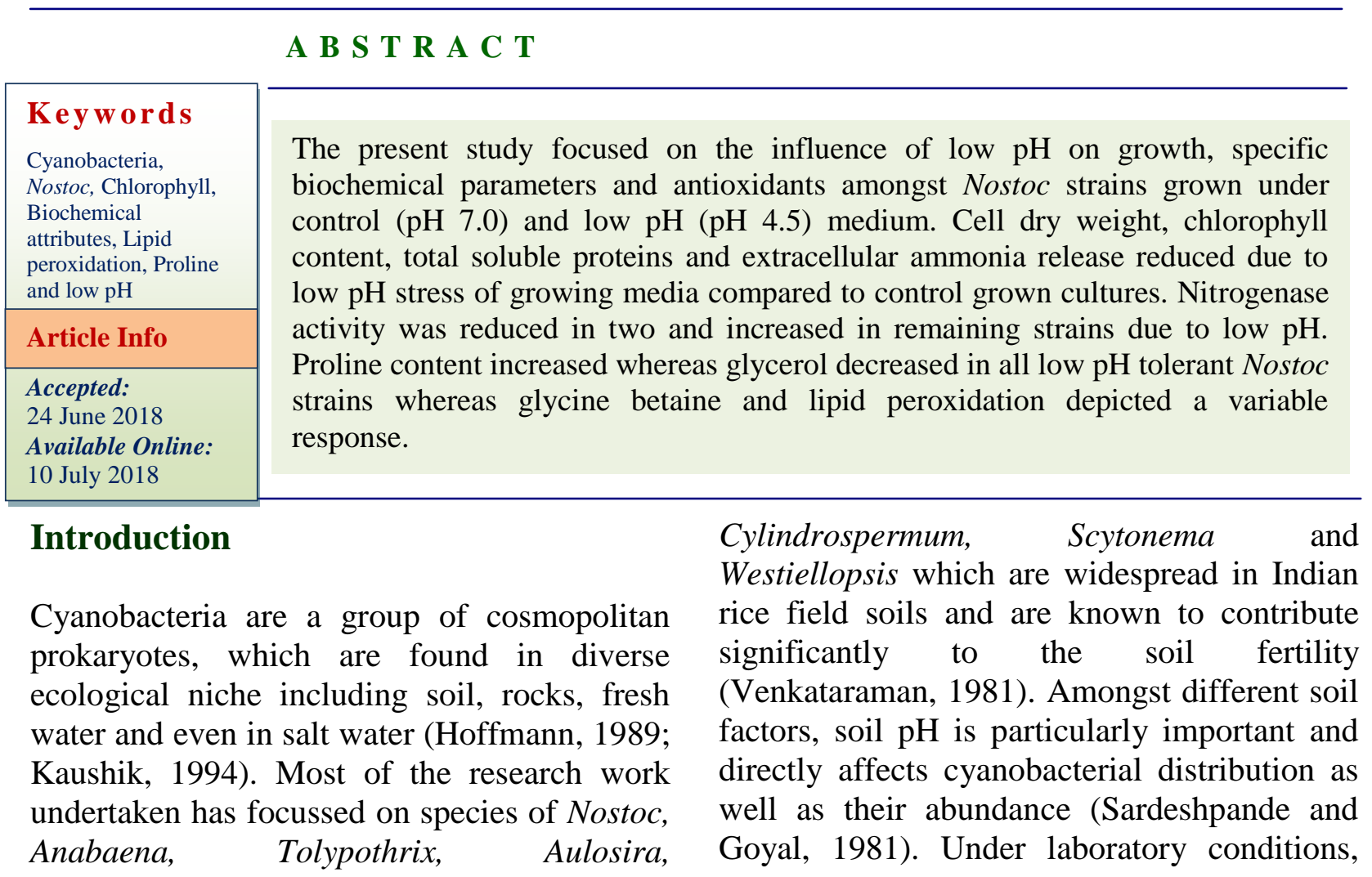


these have generally been reported to prefer neutral to slightly alkaline medium for optimum growth and are normally absent at $\mathrm{pH}$ values below 4 or 5 (Gerloff et al., 1952; Kratz et al., 1955). A phytoplankton survey of 10 lakes in Bavarian Forest as well as the lignite mining districts of Bavaria (Upper Palatine) and Lusatia, covering a $\mathrm{pH}$ gradient from 8.0 to 2.8 , demonstrated that acidtolerant cyanobacteria do exist (Steinberg et al., 1998). Low $\mathrm{pH}$ stress is a potential abiotic stress negatively affecting the growth, survival, pigmentation, protein profiles, membrane structures and biological nitrogen fixation process in cyanobacteria. In 2006, Tandeau de Marsac and Houmard reported that, to survive in extreme or variable environments, cyanobacteria have developed specific regulatory systems in addition to more general mechanisms that are equivalent to those found in other prokaryotes or photosynthetic bacteria. There is limited information on low $\mathrm{pH}$ tolerance mechanism in terms of growth and biochemical attributes, however, studies have been conducted in relation to different abiotic stresses like osmotic, salinity, organic, water and UVradiation. In view of this, the aim of the present work was to study the effect of low $\mathrm{pH}$ on growth, total soluble proteins, extracellular ammonia release, nitrogenase activity and antioxidants in selected Nostoc strains isolated from low $\mathrm{pH}$ soils of India, against fresh water isolate from IARI rice field.

\section{Materials and Methods}

\section{Cyanobacterial strains and cultural} conditions

Low $\mathrm{pH}$ tolerant Nostoc strains (Ns1, Ns2, Ns3, Ns4) isolated from acidic soils of India as well as fresh water strain Nostoc punctiforme (CCC No. 672, Ns5) which was an isolate from IARI rice field, were procured from the culture collection of CCUBGA,
ICAR-IARI. These strains were grown and maintained in BG-11 ( $\mathrm{N}$ deficient) medium at $28 \pm 2^{\circ} \mathrm{C}$ temperature under photoperiod of 16:8 hours light and dark cycle with light intensity of $52-55 \mu$ mole photon $\mathrm{m}^{-1} \mathrm{~s}^{-1}$ in culture room. The $\mathrm{pH}$ of medium for Ns1 to Ns4 was maintained at 7.0 (control) and 4.5 (low $\mathrm{pH}$ ) under two sets of experiment. Low $\mathrm{pH}$ was maintained with $0.1 \mathrm{M}$ citrate buffer $(\mathrm{pH} 3.1)$ comprising $0.1 \mathrm{M}$ Citric acid monohydrate and $0.1 \mathrm{M}$ Trisodium citrate dihyrate after filter sterilization. Nostoc punctiforme (Ns5) was grown and maintained at $\mathrm{pH} 7.0$ only as it did not tolerate low $\mathrm{pH}$ medium. Known volumes of cyanobacterial suspension grown under control $(\mathrm{pH}$ 7.0) and low $\mathrm{pH}(\mathrm{pH} 4.5)$ medium was used during exponential phase of growth $\left(14^{\text {th }}\right.$ day) for estimation of growth, specific biochemical attributes and antioxidants.

Cell dry weight (CDW, mgml ${ }^{-1}$ ) was determined gravimetrically using a known volume of cyanobacterial suspension by centrifugation at $5000 \mathrm{~g}$ for $10 \mathrm{~min}$. The washed and harvested pellet was dried at $60^{\circ} \mathrm{C}$ temperature till constant weight was achieved (Sorokin 1945). The chlorophyll content $\left(\mu \mathrm{gml}^{-1}\right)$ was estimated in methanolic extract with absorbance measured at 650 and $665 \mathrm{~nm}$ (Litchtenthaler and Buschman, 2001). Total soluble proteins were measured at $650 \mathrm{~nm}$ spectrophotometrically following the method of Lowry et al., (1951). Phenol hypochlorite method was used to estimate extracellular ammonia ( $\mu$ mole $\mathrm{NH}_{4}{ }^{+} \mathrm{ml}^{-1}$, Solorzano1969). Nitrogenase activity was measured as acetylene reducing activity following the method of Hardy et al., (1968). Proline content $\left(\mu \mathrm{gml}^{-1}\right)$ in cyanobacterial homogenate was determined spectrophotometrically according to the method of Bates et al., (1973). Modified procedures developed by Lambert and Neish (1950) and that of Grieve and Grattan (1983) were used to study glycerol $\left(\mu \mathrm{g} \mathrm{ml}^{-1}\right)$ and glycine betaine content 
$\left(\mu \mathrm{g} \mathrm{ml}^{-1}\right)$. Concentration of malondialdehyde was measured for lipid peroxidation potential ( $\mu \mathrm{g} \mathrm{ml}^{-1}$, Heath \& Packer 1968).

For statistical analyses, the triplicate set of data for the various parameters evaluated were subjected to ANOVA (analysis of variance) and the software Statistical Package for Social Sciences (SPSS Version 16.0) was used for calculating SE, SD and CD.

\section{Results and Discussion}

Comparative cell dry weight $\left(\mathrm{mg} \mathrm{ml}^{-1}\right)$ as well as chlorophyll content decreased in Ns1, Ns2, Ns3 and Ns4 under low $\mathrm{pH}$ growing conditions as compared to control, however, fresh water strain, Ns5 did not tolerate low $\mathrm{pH}$ stress and no growth was observed. The percent decrease in the cell dry weight varied from a lowest of $12 \%$ in Ns3 to the highest of $25 \%$ by Ns1 and the treatment effect was observed to be significant in all. On the other hand, percent decrease in chlorophyll content ranged from a lowest of $17 \%$ in Ns3 to the highest of $45 \%$ in Ns1 (Table 2). Cell dry weight under control grown conditions showed a highest of $1.90 \mathrm{mg} \mathrm{ml}^{-1}$ in Ns1 to the lowest of $1.19 \mathrm{mg} \mathrm{ml}^{-1}$ in Ns3. The other two strains showed cell dry weight of $1.77 \mathrm{mg} \mathrm{ml}^{-1}$ (Ns2) and $1.1 .66 \mathrm{mg} \mathrm{ml}^{-1}$ (Ns4) respectively. However, under low $\mathrm{pH}$ grown cultures, the range in cell dry weight was from a highest of $1.51 \mathrm{mg} \mathrm{ml}^{-1}$ to the lowest of $1.05 \mathrm{mg} \mathrm{ml}^{-1}$ in Ns2 and Ns3 while strains Ns1 and Ns2 depicted the cell dry weight of $1.43 \mathrm{mg} \mathrm{ml}^{-1}$ and $1.51 \mathrm{mg} \mathrm{ml}^{-1}$ respectively. The fresh water strain showed cell dry weight of $1.32 \mathrm{mg} \mathrm{ml}^{-1}$ under normal pH of 7.0 (Table 1). Nostoc strains which were isolated from low $\mathrm{pH}$ soils of India exhibited growth at $\mathrm{pH}$ of 4.5 which is in accordance as reported by Rai and Rajsekhar (1989), which showed the growth of cyanobacteria strains at $\mathrm{pH}$ 6.3. Earlier study related to $\mathrm{pH}$ effect on the growth of cyanobacteria has revealed that the $\mathrm{pH}$ between 7.4 and 8.0 is optimum (Rippka et al., 1979; Bano and Siddiqui, 2004). The $\mathrm{pH}$ of the medium determines the solubility of $\mathrm{CO}_{2}$ and minerals in the medium, which in turn can directly or indirectly influence metabolism of these organisms. The $\mathrm{pH}$ tolerance has been reported by Venkatraman (1972) and these organisms can grow at a $\mathrm{pH}$ range of 6.5 to 10 (Nagle et al., 2010). However, some strains have been reported to grow at a $\mathrm{pH}$ as low as 3.5 (Aiyer et al., 1965). In cultures grown under control conditions, strain Ns1 showed highest chlorophyll content of $18.70 \mu \mathrm{g} \mathrm{ml}^{-1}$ whereas strain Ns4 showed lowest chlorophyll content of $12.66 \mu \mathrm{g} \mathrm{ml}^{-1}$, the other two strains Ns2 and Ns3 showed the chlorophyll content of $13.00 \mu \mathrm{g} \mathrm{ml}^{-1}$ and $15.55 \mu \mathrm{g} \mathrm{m} \mathrm{m}^{-1}$ respectively. The fresh water isolate Ns5 showed chlorophyll content of $16.76 \mu \mathrm{g} \mathrm{ml}^{-1}$. However, due to low $\mathrm{pH}$, chlorophyll content was ranged from highest of $12.91 \mu \mathrm{g} \mathrm{ml}^{-1}$ (Ns3) to the lowest of $7.58 \mu \mathrm{g} \mathrm{ml}^{-1}$ (Ns2) while in Ns1 and Ns4 it was $10.22 \mu \mathrm{g} \mathrm{ml}^{-1}$ and 9.01 $\mu \mathrm{g} \mathrm{ml}^{-1}$ (Table 1). The reduction in chlorophyll content under low $\mathrm{pH}$ stress condition may be due to inhibition of chlorophyll biosynthesis by affecting important enzymes like, $\alpha$-aminolevulinic acid dehydrogenase and protochlorophyllide reductase, involved in pigment synthesis (Ouzounidou 1995). Huang et al., (2002) also reported that low $\mathrm{pH}$ of the medium resulted in the decrease of growth and pigmentation in cyanobacterium Synechocystis sp. strain PCC 6308.

Total soluble proteins also decreased due to low pH stress in Nostoc strains (Ns1, Ns2, Ns3 and Ns4) as compared to normal $\mathrm{pH}$ growing conditions. The fresh water isolate, Ns5 showed the total soluble proteins of $0.71 \mathrm{mg}$ $\mathrm{ml}^{-1}$ under control grown conditions. Percent reduction in total soluble proteins was observed to be in the range of $14 \%$ to $24 \%$ by Ns4 and Ns2 due to low pH stress (Table 2). The total soluble proteins were highest 
$\left(0.93 \mathrm{mg} \mathrm{ml}^{-1}\right)$ in Ns1 and lowest $(0.69 \mathrm{mg}$ $\mathrm{ml}^{-1}$ ) in Ns4 while Ns2 and Ns3 depicted a total soluble proteins content $0.78 \mathrm{mg} \mathrm{ml}^{-1}$ and $0.80 \mathrm{mg} \mathrm{ml}^{-1}$ at $\mathrm{pH}$ 7.0. At $\mathrm{pH} \mathrm{4.5,} \mathrm{Ns1}$ showed highest $\left(0.73 \mathrm{mg} \mathrm{ml}^{-1}\right)$ followed by $0.69 \mathrm{mg} \mathrm{ml}^{-1}$ (Ns3), $0.59 \mathrm{mg} \mathrm{ml}^{-1}$ (Ns4) and Ns2 showed lowest $\left(0.59 \mathrm{mg} \mathrm{ml}^{-1}\right)$ total soluble proteins (Table 1). Extracellular ammonia release is a very important attribute of heterocystous cyanobacteria and ranged from a highest of $275.20 \mu$ mole $\mathrm{NH}_{4}{ }^{+} \mathrm{ml}^{-1}$ (Ns1) to lowest of $68.90 \mu$ mole $\mathrm{NH}_{4}{ }^{+} \mathrm{ml}^{-1}$ (Ns4), while the other two strains Ns2 and Ns3 depicted $191.10 \mu$ mole $\mathrm{NH}_{4}^{+} \mathrm{ml}^{-1}$ and $87.70 \mu$ mole $\mathrm{NH}_{4}{ }^{+} \mathrm{ml}^{-1}$ under control grown conditions. When these cultures were grown under low $\mathrm{pH}$ medium, the extracellular ammonia release ranged from $165.10 \mu$ mole $\mathrm{NH}_{4}{ }^{+} \mathrm{ml}^{-1}$ in Ns1 to $30.70 \mu$ mole $\mathrm{NH}_{4}{ }^{+} \mathrm{ml}^{-1}$ in Ns4 while, the Strains Ns2 and Ns3 depicted the extracellular ammonia release of 75.10 $\mu$ mole $\mathrm{NH}_{4}{ }^{+} \mathrm{ml}^{-1}$ and $38.80 \mu$ mole $\mathrm{NH}_{4}{ }^{+} \mathrm{ml}^{-1}$ respectively. Fresh water isolate showed an extracellular ammonia release of 103.40 umole $\mathrm{NH}_{4}^{+} \mathrm{ml}^{-1}$ and percent decrease in extracellular ammonia release varied as a highest of $61 \%$ to the lowest of $40 \%$ in Ns2 and Ns1 due to low $\mathrm{pH}$ stress in the growing medium (Table 2). The reduction in extracellular ammonia release could be due to enhanced glutamine synthetase activity or reduced nitrogenase activity under low $\mathrm{pH}$ stress condition.

Fresh water strain does not tolerate low $\mathrm{pH}$ stress growing condition as cyanobacteria have been reported to prefer alkaline condition for their growth which suggests that there is probably an acid barrier which these organisms are not able to overcome, hence, this group of algae is excluded from low $\mathrm{pH}$ environment. However, in other strains of Nostoc (Ns1, Ns2, Ns3, Ns4) there was a significant decrease observed in cell dry weight, chlorophyll content, total soluble proteins and extracellular ammonia release due to low $\mathrm{pH}$ stress which could be as a result of lack of control over internal $\mathrm{pH}$ resulting in growth limitation (Padan et al., 1981; Booth 1985; Padan and Schuldiner 1987). At low $\mathrm{pH}$, cells spend energy for maintenance of internal $\mathrm{pH}$ necessary for important cell functions (Raven and Lucas 1985). Low $\mathrm{pH}$ tolerance shown by cyanobacteria suggests that these organisms can adapt to variable $\mathrm{pH}$ conditions (Burja et al., 2002). However, the growth rate of diatoms was not affected by $\mathrm{pH}$ range of 7.4 to 8.2 and it was significantly lower at $\mathrm{pH}$ of 6.8 . Highest nitrogenase activity of 1.96 nmole $\mathrm{C}_{2} \mathrm{H}_{4} \quad \mathrm{ml}^{-1} \mathrm{~h}^{-1}$ was exhibited by $\mathrm{Ns} 2$ followed by 0.30 nmole $\mathrm{C}_{2} \mathrm{H}_{4} \mathrm{ml}^{-1} \mathrm{~h}^{-1}$ in Ns1, 0.32 nmole $\mathrm{C}_{2} \mathrm{H}_{4} \mathrm{ml}^{-1} \mathrm{~h}^{-1}$ in Ns3 and the lowest of $0.28 \mathrm{nmole}_{2} \mathrm{H}_{4} \mathrm{ml}^{-}$ ${ }^{1} \mathrm{~h}^{-1}$ was shown in Ns4 under control grown culture conditions. When the cultures were grown under low $\mathrm{pH}$ stress medium, nitrogenase activity dropped to a highest of 0.83 nmole $\mathrm{C}_{2} \mathrm{H}_{4} \mathrm{ml}^{-1} \mathrm{~h}^{-1}$ in Ns3 and lowest of 0.27 nmole $\mathrm{C}_{2} \mathrm{H}_{4} \mathrm{ml}^{-1} \mathrm{~h}^{-1}$ in Ns1. The other two strains, Ns2 and Ns4 showed the nitrogenase activity of 0.64 nmole $\mathrm{C}_{2} \mathrm{H}_{4} \mathrm{ml}^{-1} \mathrm{~h}^{-1}$ and 0.64 nmole $\mathrm{C}_{2} \mathrm{H}_{4} \quad \mathrm{ml}^{-1} \mathrm{~h}^{-1}$ respectively (Table 1 ). Low $\mathrm{pH}$ stress condition reduced the nitrogenase activity by $10 \%$ and $67 \%$ in Nostoc strains Ns1 and Ns2, however, it increased in Ns3 and Ns4 by $159 \%$ and $139 \%$ and fresh water isolate showed nitrogenase activity of 1.73 nmole $\mathrm{C}_{2} \mathrm{H}_{4} \mathrm{ml}^{-1} \mathrm{~h}^{-1}$ (Table 2). There was a strain variability recorded in terms of expression of nitrogenase activity due to low $\mathrm{pH}$ condition. Comparative evaluation of selected parameters amongst Nostoc strains grown under control $(\mathrm{pH} 7.0)$ and low $\mathrm{pH}(\mathrm{pH}$ 4.5) conditions depicted that Nostoc strain Ns1, an isolate from Alipurduar (West Bengal), India showed maximum cell dry weight, chlorophyll content, total soluble proteins and extracellular ammonia release while Ns4 (an isolate from Mokokchung, Nagaland soil) showed lowest chlorophyll, total soluble proteins and extracellular ammonia release under control $(\mathrm{pH}$ 7.0) 
grown conditions. The cell dry weight was lowest in Ns3, which was an isolate from Ernakulum Kerala soil. When these cultures were grown under low $\mathrm{pH}$ medium, Ns1 again depicted highest total soluble proteins and extracellular ammonia release, whereas, Ns2 showed highest cell dry weight and Ns3 exhibited maximum chlorophyll content. On the other hand Ns2 showed lowest chlorophyll content and total soluble proteins, whereas, cell dry weight was lowest in Ns3 and extracellular ammonia release was lowest in Ns4.

Results calculated for non-enzymatic antioxidants namely proline, glycerol, glycine betaine and lipid peroxidation indicated a variable behaviour by Nostoc strains grown under control and low $\mathrm{pH}$ conditions. The low $\mathrm{pH}$ stress enhanced selected antioxidants like proline, lipid peroxidation and glycine betaine, however, a reverse trend was shown in terms of glycerol accumulation. Proline content increased in Nostoc strains under $\mathrm{pH} 4.5$ as compared to control grown cultures. Under low $\mathrm{pH}$ stress, the highest proline content of $132.80 \mu \mathrm{g} \mathrm{ml}^{-1}$ was recorded in Ns1 and the lowest of $76.68 \mu \mathrm{g} \mathrm{ml}^{-1}$ was shown by Ns3. The other two strains showed proline content of $102.63 \mu \mathrm{g} \mathrm{ml}^{-1}$ (Ns2) and $101.47 \mu \mathrm{g} \mathrm{ml}^{-1}$ (Ns4) respectively. When Nostoc strains were grown at control $\mathrm{pH}$ medium, the proline content of $86.38 \mu \mathrm{g} \mathrm{ml}^{-1}$ was highest in Ns2 followed by a proline content of $75.54 \mu \mathrm{g} \mathrm{ml}^{-1}$ (Ns1), $64.76 \mu \mathrm{g} \mathrm{ml}^{-1}$ (Ns4) with the lowest of $61.70 \mu \mathrm{g} \mathrm{ml}^{-1}$ (Ns3). Fresh water isolate showed a proline content of $64.34 \mu \mathrm{g} \mathrm{ml}^{-1}$ which was similar to the proline content depicted by Ns4 (Table 3).

Table.1 Comparative Cell Dry Weight $\left(\mathrm{CDW}, \mathrm{mg} \mathrm{ml}^{-1}\right)$, chlorophyll $\left(\mu \mathrm{g} \mathrm{ml}^{-1}\right)$, total soluble proteins $\left(\mathrm{TSP}, \mathrm{mgml}^{-1}\right)$, extracellular ammonia release $\left(\mathrm{EAR}, \mu\right.$ mole $\mathrm{ml}^{-1}$ ) and nitrogenase activity (nmoles $\mathrm{C}_{2} \mathrm{H}_{4} \mathrm{ml}^{-1} \mathrm{~h}^{-1}$ ) amongst selected Nostoc strains grown under control (pH-7.0) and low $\mathrm{pH}(\mathrm{pH}-4.5)$ conditions (Mean $\pm \mathrm{SD} ; \mathrm{n}=3$ )

\begin{tabular}{|c|c|c|c|c|c|}
\hline $\begin{array}{l}\text { Strains*/ } \\
\text { Treatments }\end{array}$ & CDW & Chlorophyll & TSP & EAR & Nitrogenase $e^{\ddagger}$ \\
\hline Ns1 C1 & $1.90 \pm 0.076^{\mathrm{a}}$ & $18.70 \pm 1.108^{\mathrm{a}}$ & $0.93 \pm 0.055^{\mathrm{a}}$ & $275.20 \pm 3.995^{\mathrm{a}}$ & $0.30 \pm 0.003^{\mathrm{e}}$ \\
\hline $\mathrm{T} 1$ & $1.43 \pm 0.053^{\mathrm{de}}$ & $10.22 \pm 2.656^{\mathrm{d}}$ & $0.73 \pm 0.013^{b c}$ & $165.10 \pm 1.212^{c}$ & $0.27 \pm 0.006^{\mathrm{e}}$ \\
\hline Ns2 $\mathrm{C} 2$ & $1.77 \pm 0.020^{\mathrm{b}}$ & $13.00 \pm 0.847^{\mathrm{c}}$ & $0.78 \pm 0.029^{b}$ & $191.10 \pm 2.163^{b}$ & $1.96 \pm 0.055^{\mathrm{a}}$ \\
\hline $\mathrm{T} 2$ & $1.51 \pm 0.102^{\mathrm{d}}$ & $7.58 \pm 1.589^{\mathrm{e}}$ & $0.59 \pm 0.033^{\mathrm{d}}$ & $75.10 \pm 1.539^{f}$ & $0.64 \pm 0.001^{\mathrm{d}}$ \\
\hline Ns3 & $1.19 \pm 0.068^{\mathrm{g}}$ & $15.55 \pm 0.674^{b}$ & $0.80 \pm 0.016^{b}$ & $87.70 \pm 1.652^{\mathrm{e}}$ & $0.32 \pm 0.013^{\mathrm{e}}$ \\
\hline T3 & $1.05 \pm 0.080^{\mathrm{h}}$ & $12.91 \pm 0.201^{\mathrm{c}}$ & $0.69 \pm 0.026^{c}$ & $38.80 \pm 0.458^{h}$ & $0.83 \pm 0.003^{c}$ \\
\hline Ns4 & $1.66 \pm 0.054^{\mathrm{c}}$ & $12.66 \pm 0.117^{\mathrm{c}}$ & $0.69 \pm 0.064^{c}$ & $68.90 \pm 2.272^{\mathrm{g}}$ & $0.28 \pm 0.011^{\mathrm{e}}$ \\
\hline $\mathrm{T} 4$ & $1.39 \pm 0.017^{\mathrm{ef}}$ & $9.01 \pm 0.063^{\mathrm{de}}$ & $0.59 \pm 0.027^{\mathrm{d}}$ & $30.70 \pm 1.353^{i}$ & $0.67 \pm 0.010^{\mathrm{d}}$ \\
\hline Ns5 C5 & $1.32 \pm 0.024^{\mathrm{f}}$ & $16.76 \pm 0.734^{\mathrm{ab}}$ & $0.71 \pm 0.026^{c}$ & $103.40 \pm 2.551^{d}$ & $1.73 \pm 0.041^{b}$ \\
\hline $\mathrm{T} 5$ & $\mathrm{ND}^{\#}$ & ND & ND & ND & ND \\
\hline $\operatorname{SEm}( \pm)$ & 0.037 & 0.617 & 0.021 & 1.285 & 0.015 \\
\hline $\mathrm{CD}(0.05 \%)$ & 0.112 & 1.850 & 0.063 & 3.854 & 0.044 \\
\hline
\end{tabular}

* Nostoc strains (Ns1, Ns2, Ns3, Ns4, Ns5)

T Treatments: Control (C1, C2, C3, C4, C5); low pH (T1, T2, T3, T4, T5)

$\neq$ Acetylene reducing activity

Different superscripts in the same column represent significant differences between samples $(\mathrm{p}<0.05)$

${ }^{\#}$ ND- Not detected 
Table.2 Percent change in cell dry weight (CDW), chlorophyll, total soluble proteins (TSP), extracellular ammonia release (EAR) and nitrogenase activity amongst selected Nostoc strains under low $\mathrm{pH}$ stress condition as compared to control

\begin{tabular}{|c|c|c|c|c|c|}
\hline Strains & CDW & Chlorophyll & TSP & EAR & Nitrogenase \\
\hline Ns1 & $25 \% \downarrow$ & $45 \%$ & $22 \% \downarrow$ & $40 \% \downarrow$ & $10 \% \downarrow$ \\
\hline Ns2 & $15 \% \downarrow$ & $42 \% \downarrow$ & $24 \% \downarrow$ & $61 \% \downarrow$ & $67 \% \downarrow$ \\
\hline Ns3 & $12 \% \downarrow$ & $17 \% \downarrow$ & $14 \% \downarrow$ & $56 \% \downarrow$ & $159 \%$ \\
\hline Ns4 & $16 \%$ & $29 \%$ & $14 \%$ & $55 \%$ & $139 \%$ \\
\hline
\end{tabular}

*Arrows denotes percent increase $(\mathbf{\varphi})$ and decrease $(\downarrow)$ in specific parameter

Table.3 Comparative proline $\left(\mu \mathrm{g} \mathrm{mg}^{-1}\right)$, glycerol $\left(\mu \mathrm{g} \mathrm{mg}^{-1}\right)$, glycine betaine $\left(\mu \mathrm{g} \mathrm{mg}^{-1}\right)$ and lipid peroxidation $\left(\mu \mathrm{g} \mathrm{mg}^{-1}\right)$ amongst selected Nostoc strains grown under control $(\mathrm{pH}-7.0)$ and low $\mathrm{pH}(\mathrm{pH}-4.5)$ condition (Mean $\pm \mathrm{SD} ; \mathrm{n}=3$ )

\begin{tabular}{|c|c|c|c|c|c|}
\hline $\begin{array}{c}\text { Strains*/ } \\
\text { Treatments }\end{array}$ & Proline & Glycerol & Glycine betaine & $\begin{array}{c}\text { Lipid } \\
\text { peroxidation }\end{array}$ \\
\hline Ns1 & C1 & $75.94 \pm 1.279^{\mathrm{d}}$ & $34.10 \pm 1.463^{\mathrm{d}}$ & $200.76 \pm 2.001^{\mathrm{a}}$ & $4.19 \pm 0.047^{\mathrm{b}}$ \\
\hline & T1 & $132.80 \pm 2.558^{\mathrm{a}}$ & $28.79 \pm 0.770^{\mathrm{e}}$ & $109.22 \pm 1.044^{\mathrm{g}}$ & $3.48 \pm 0.068^{\mathrm{c}}$ \\
\hline Ns2 & C2 & $86.38 \pm 0.483^{\mathrm{c}}$ & $46.60 \pm 1.016^{\mathrm{b}}$ & $145.55 \pm 0.688^{\mathrm{f}}$ & $3.24 \pm 0.094^{\mathrm{d}}$ \\
\hline & T2 & $102.63 \pm 1.675^{\mathrm{b}}$ & $25.74 \pm 0.438^{\mathrm{f}}$ & $162.18 \pm 0.168^{\mathrm{c}}$ & $5.96 \pm 0.060^{\mathrm{a}}$ \\
\hline Ns3 & C3 & $61.70 \pm 0.796^{\mathrm{f}}$ & $34.28 \pm 0.194^{\mathrm{d}}$ & $151.18 \pm 1.529^{\mathrm{e}}$ & $2.18 \pm 0.013^{\mathrm{g}}$ \\
\hline & T3 & $76.68 \pm 0.633^{\mathrm{d}}$ & $14.83 \pm 0.848^{\mathrm{h}}$ & $200.73 \pm 2.988^{\mathrm{a}}$ & $2.85 \pm 0.073^{\mathrm{e}}$ \\
\hline Ns4 & C4 & $64.76 \pm 0.659^{\mathrm{e}}$ & $42.19 \pm 0.308^{\mathrm{e}}$ & $185.35 \pm 0.175^{\mathrm{b}}$ & $2.51 \pm 0.013^{\mathrm{f}}$ \\
\hline & T4 & $101.47 \pm 3.186^{\mathrm{b}}$ & $21.09 \pm 1.272^{\mathrm{g}}$ & $155.41 \pm 1.379^{\mathrm{d}}$ & $2.85 \pm 0.026^{\mathrm{e}}$ \\
\hline Ns5 & C5 & $64.34 \pm 1.096^{\mathrm{ef}}$ & $48.76 \pm 0.321^{\mathrm{a}}$ & $162.04 \pm 0.679^{\mathrm{c}}$ & $3.50 \pm 0.045^{\mathrm{c}}$ \\
\hline & T5 & ND $^{\#}$ & ND & ND & ND \\
\hline SEm $( \pm)$ & $\mathbf{0 . 9 9 6}$ & $\mathbf{0 . 5 0 1}$ & $\mathbf{0 . 7 8 9}$ & $\mathbf{0 . 0 3 2}$ \\
\hline CD $(0.05 \%)$ & $\mathbf{2 . 9 8 7}$ & $\mathbf{1 . 5 0 1}$ & $\mathbf{2 . 3 6 6}$ & $\mathbf{0 . 0 9 7}$ \\
\hline
\end{tabular}

* Nostoc strains (Ns1, Ns2, Ns3, Ns4, Ns5)

T Treatments: control (C1, C2, C3, C4, C5); low pH (T1, T2, T3, T4, T5)

Different superscripts in the same column represent significant differences between samples $(\mathrm{p}<0.05)$ ${ }^{\#}$ ND- Not detected

Table.4 Percent change in proline, glycerol, glycine betaine and lipid peroxidation amongst selected Nostoc strains under low $\mathrm{pH}$ stress condition as compared to control

\begin{tabular}{|c|c|c|c|c|}
\hline Strains & Proline & Glycerol & Glycine betaine & Lipid peroxidation \\
\hline Ns1 & $75 \% \uparrow$ & $16 \%$ & $46 \% \downarrow$ & $17 \%$ \\
\hline Ns2 & $19 \%$ & $45 \% \downarrow$ & $11 \% \uparrow$ & $84 \%$ \\
\hline Ns3 & $24 \% \uparrow$ & $57 \%$ & $33 \% \uparrow$ & $31 \%$ \\
\hline Ns4 & $57 \% \uparrow$ & $50 \% \downarrow$ & $16 \%$ & $14 \%$ \\
\hline
\end{tabular}

*Arrows denotes percent increase $(\mathbf{\uparrow})$ and decrease $(\downarrow)$ in specific parameter 
Glycerol content also decreased due to low $\mathrm{pH}$ stress compared to control and the percent decrease varied from $16 \%$ in Ns1 to $57 \%$ in Ns3 (Table 4). Fresh water isolate (Ns5) showed a highest glycerol content of $48.76 \mu \mathrm{g}$ $\mathrm{ml}^{-1}$, followed by glycerol content of $46.60 \mu \mathrm{g}$ $\mathrm{ml}^{-1}$ (Ns2), $42.19 \mu \mathrm{g} \mathrm{ml}^{-1}$ (Ns4), $34.28 \mu \mathrm{g} \mathrm{ml}^{-1}$ (Ns3) with the lowest of $34.10 \mu \mathrm{g} \mathrm{ml}^{-1}$ (Ns1) under control grown conditions. However at low $\mathrm{pH}$, the glycerol content was highest $\left(28.79 \mu \mathrm{g} \mathrm{ml}^{-1}\right)$ in Ns1 and lowest $(14.83 \mu \mathrm{g}$ $\mathrm{ml}^{-1}$ ) in Ns3, while the other two strains, Ns2 and Ns4 depicted the glycerol content of $25.74 \mu \mathrm{g} \mathrm{ml}^{-1}$ and $21.09 \mu \mathrm{g} \mathrm{ml}^{-1}$ respectively (Table 3). Glycine betaine was highest (200.76 $\mathrm{ug} \mathrm{ml}^{-1}$ ) in Ns1 followed by 151.18 $\mu \mathrm{g} \mathrm{m}{ }^{-1}$ in Ns3, $185.35 \mu \mathrm{g} \mathrm{ml}^{-1}$ in Ns4 and Ns2 showed a lowest glycine betaine of $145.55 \mu \mathrm{g} \mathrm{ml}^{-1}$ at $\mathrm{pH} 7.0$ whereas, fresh water isolate depicted a glycine betaine level of $162.04 \mu \mathrm{g} \mathrm{ml}^{-1}$ which was at par with the glycine betaine content of $162.18 \mu \mathrm{g} \mathrm{ml}^{-1}$ under low $\mathrm{pH}$ stress by Ns2. Under $\mathrm{pH}$ stress, the glycine betaine was highest $(200.73 \mu \mathrm{g}$ $\mathrm{ml}^{-1}$ ) in Ns3 whereas Ns1 showed lowest (109.22 $\mu \mathrm{g} \mathrm{ml} \mathrm{ml}^{-1}$ glycine betaine content while, the other two strains, Ns2 and Ns4 showed $162.18 \mu \mathrm{g} \mathrm{ml}^{-1}$ and $155.41 \mu \mathrm{g} \mathrm{ml}^{-1}$ of glycine betaine content respectively (Table 3). Nostoc strains exhibited a variable behaviour in terms of glycine betaine which increased by $11 \%$ and $33 \%$ in Ns2 and Ns3 due to low $\mathrm{pH}$ stress, whereas a decrease of $16 \%$ and $46 \%$ was recorded by Ns4 and Ns1 (Table 4). Lipid peroxidation also depicted a variability in terms of response towards low $\mathrm{pH}$ stress vis-à-vis control grown cultures with the highest of $4.19 \mu \mathrm{g} \mathrm{ml}^{-1}$ recorded by Ns1 and lowest of $2.18 \mu \mathrm{g} \mathrm{ml}^{-1}$ recorded by Ns3 under $\mathrm{pH}$ 7.0. The fresh water isolate showed lipid peroxidation of $3.50 \mu \mathrm{g} \mathrm{ml}^{-1}$. At low $\mathrm{pH}$, Ns2 showed highest $\left(5.96 \mu \mathrm{g} \mathrm{ml}^{-1}\right)$ lipid peroxidation followed by Ns1 $(3.48 \mu \mathrm{g}$ $\left.\mathrm{ml}^{-1}\right)$, Ns3 (2.85 $\left.\mu \mathrm{g} \mathrm{ml}^{-1}\right)$ and Ns4 (2.83 $\mu \mathrm{g}$ $\mathrm{ml}^{-1}$ ) (Table 3). Lipid peroxidation was more or less similar in Ns3 and Ns4 when the cultures were grown under control $(\mathrm{pH} 7.0)$ and/or low $\mathrm{pH}$ stress condition. Lipid peroxidation decreased by $17 \%$ in Ns1 and increased by $84 \%, 31 \%$ and $14 \%$ in Ns2, Ns3 and $\mathrm{Ns} 4$ due to low $\mathrm{pH}$ stress as compared to control (Table 4). High degree of lipid peroxidation has been reported in Synechococcus and Nostoc muscorum (Rehman et al., 2011). Stress induced enhancement in these parameters is supported by the reports of Zeesan and Prasad (2009) and Sunderam et al., (2011). The stress and the resistance is governed through modulation of antioxidant enzymes as well as compounds like proline, glycine betaine, glutathione and ascorbate and their increased malondialdehyde levels. Increased level of these antioxidants under stress condition is indicative of a correlation between free radical generation and proline accumulation (Zeesan and Prasad 2009). This is in agreement with other reports on Spirulina platensis and Westeillopsis prolifica (Choudhary et al.2007). The cyanobacteria can counteract the toxic effect of abiotic stress induced free radicals by increasing antioxidants defense mechanisms.

Under control conditions of growth, proline content was highest in Ns 2, whereas glycerol was maximum in Ns5 and Ns1 showed maximum glycine betaine and lipid peroxidation. However, the proline and lipid peroxidation was lowest in Ns3, while glycerol and glycine betaine were lowest in Ns1 and Ns2. Highest proline content and glycerol was depicted by Ns1 whereas glycine betaine and lipid peroxidation were maximum in Ns3 and Ns2 when cultures were grown under low $\mathrm{pH}$ stress. With $\mathrm{pH}$ stress proline and lipid peroxidation were lowest in Ns4 whereas, glycerol was lowest in Ns3 and glycine betaine was lowest in Ns1.

In conclusions, comparative studies undertaken amongst Nostoc strains indicated 
that low $\mathrm{pH}$ condition in the growing medium reduced growth in terms of cell dry weight, chlorophyll content, extracellular ammonia release and total soluble proteins. The influence of low $\mathrm{pH}$ on nitrogenise activity was variable. Low $\mathrm{pH}$ stress increased proline content and increased glycerol, however, its influence on other parameters like glycine betaine and lipid peroxidation was variable. The study clearly indicated the differential behaviour of Nostoc strains in terms of selected parameters due to low $\mathrm{pH}$ stress situations and such strains can be further used to understand the in-depth mechanisms underlying low $\mathrm{pH}$ tolerance amongst cyanobacteria.

\section{Acknowledgment}

The results given are the findings of Ph.D. work of Ms. Himani Priya from Post Graduate School, ICAR-IARI, New Delhi. The facilities provided by the Division of Microbiology and CCUBGA are gratefully acknowledged. The first author is also grateful to CSIR for JRF grant.

\section{References}

Aiyer, R.S. (1965). Comparative algological studies in rice fields in Kerala state. Agricultural Research Journal of Kerala. 3(1): 100-104.

Bano, A. and P. J. A. Siddiqui. (2004). Characterization of five marine cyanobacterial species with respect to their $\mathrm{pH}$ and salinity requirements. Pakistan Journal of Botany. 36: 133 143.

Bates, K.S., Wadern, R.P. and Teare, I.D. (1973). Rapid estimation of free proline for water stress determination. Plant, Soil and Environment. 39:205207.

Booth I.R. (1985). Regulation of cytoplasmic $\mathrm{pH}$ in bacteria. Microbiological
Reviews. 49: 359-378.

Burja, A.M., Abu-Mansour, E., Banaigs, B., Pyari, C., Burgess, J. G. and Wright, P.C. (2002). Culture of marine cyanobacterium, Lyngbya majuscula (Oscillatoriaceae), for bioprocess intensified production of cyclic and linear lipopeptides. Journal of Microbiological Methods. 48: 207 219.

Choudhary M, Jetley UK, Abash Khan M, Zutshi S, Fatma T. (2007). Effect of heavy metal stress on proline, malondialdehyde, and superoxide dismutase activity in the cyanobacterium Spirulina platensisS5. Ecotoxicology and Environmental Safety. 66(2):204-209.

Gerloff, G.C., Fitzgerald, G.P. and Skoog R. (1952). The mineral nutrition of Microcsystis aerugino. American Journal of Botany. 39: 26-32.

Greive, C.M. and Grattan, S.R. (1983). Rapid assay for determination of watersoluble quaternary amino compounds. Plant and Soil. 70: 303-307.

Hardy T.W.F., Holsten R.D., Jackson E.K., Burns R.C. (1968). The acetylene reduction assays for $\mathrm{N}_{2}$ fixation. Laboratory and field evaluation. Plant Physiology. 43:1185-1207

Heath R.L., Packer L. (1968). Photoperoxidation in isolated chloroplasts. I. Kinetics and stoichiometry of fatty acid peroxidation. Archives in Biochemistry and Biophysics 125: 189-198.

Hoffmann, L. (1989). Algae of terrestrial habitats. The Botanical Review. 55: 77-105.

Huang, J.J., Kolodony, N. H., Redfeam, J.T. and Allen, M. M. (2002). Physiological responses of acid stress in the cyanobacterium Synechocystis sp. Strain PCC 6308. Archives of 
Microbiology. 177:486-493.

Kaushik, B.D. (1994). Algalization of rice in salt-affected soils. Annals of Agricultural Research. 14: 105-106.

Kratz, W.A. and Myers J. (1955). Nutrition and growth of several blue green algae. American Journal of Botany. 42: 282-287.

Lambert, M., and Neish, A. C., (1950).Canadian Journal of Research. 28 B 83

Lichtenthaler, H.K. and Buschmann, C. (2001). Chlorophylls and Carotenoids: Measurement and Characterization by UV-VIS Spectroscopy. Current Protocols in Food Analytical Chemistry. John Wiley and Sons, New York. F4.3.1-F4.3.8.

Lowry O.H., Rosebrough N.J., Farr A.L. and Randall R.J. (1951). Protein measurement with folin-phenol reagent. The Journal of Biological Chemistry. 193:266-275.

Nagle, V. L., Mhalsekar, M. N. and Jagtap, T.G. (2010). Isolation, optimization and characterization of selected cyanophycean members. Indian Journal of Geo-Marine Sciences. 39: 212-218.

Ouzounidou, G., (1995). Cu-ions mediated changes in growth, chlorophyll and other ion contents in a Cu-tolerant Koeleria splendens. Biologia Plantarum. 37: 71-78.

Padan, E. and Schuldiner, S. (1987). Intracellular $\mathrm{pH}$ and membrane potential as regulators in The prokaryotic cell. The Journal of Membrane Biology. 95: 189-198.

Padan, E., Zilherstein, D. and Schuldiner, S. (1981). pH homeostasis in bacteria. Biochimica et Biophysica Acta. 650: 151-166.

Rahman, Md. A., Soumya, K.K., Tripathi, A., Sundaram, S., Singh, S. and Gupta, A. (2011). Evaluation and sensitivity ofcyanobacteria, Nostoc muscorum and Synechococcus PCC 7942 for heavymetals stress - a step toward biosensor. Toxicological \& Environmental Chemistry. 93(10):1982-1990.

Rai, S.V. and Rajashekhar, M. (2014). Effect of $\mathrm{pH}$, salinity and temperature on the growth of six species of marine phytoplankton. Journal of Algal Biomass Utilization. 5 (4): 55-59

Raven, J. A. and W. J. Lucas. (1985). Energy costs of carbon acquisition. In: Lucas, W. J. and J. A. Berry (Eds), Inorganic Carbon Uptake by Aquatic Phytosynthetic Organisms. American Society of Plant Physiologists. Rockville. pp 305 - 324.

Rippka, R., Deruelles, J., Waterbury, J.B., Herdman, M. and Stanier, R.Y. (1979). Generic assignments, strain histories and properties of pure cultures of cyanobacteria. Journal of General Microbiology. 111: 1-61.

Sardeshpande, J.S. and Goyal, S.K. (1981). Distributional pattern of blue green algae in rice field soils of Konkan region of Maharastra State. Journal of the Phycological Society. 20:102-106.

Solorzano, L. (1969). Determination of ammonia in natural water by the phenolhypochlorite method. Limnology and Oceanography. 14: 799-801.

Sorokin, C. (1941). Dry weight, packed cell volume and optical density. In Handbook of Phycological Methods, Culture Methods and Growth Measurements (ed. Stein, J. R.), Cambridge University Press, London Pp. 321-343.

Steinberg, C.W.E., Schafer, H. and Beisker, W. (1998). Do acid tolerant cyanobacteria exist? Acta hydrobiologic, 26: 13-19

Sundaram, S., Soumya, K.K., Ramgopal, 
Pandey, J.K. and Rahman, A. (2011). Impact of Organic Stress on Growth, Photosynthetic and Physiological Responses of Some Cyanobacterial Isolates. Journal of Environmental Science and Technology. 4(3): 264283.

Tandeau de Marsac, N. and Houmard, J. (2006). Adaptation of cyanobacteria to environmental stimuli: new steps towards molecular mechanisms. FEMS Microbiology Letters. 104: 119-189.
Venkataraman, G.S. (1981). Blue green for rice production - a manual for its promotion. FAO soils bulletin no. 46. FAO, Rome

Zeeshan, M., Prasad, S.M., (2009). Differential response of growth, photosynthesis, antioxidant enzymes and lipid peroxidation to UV-B radiation in three cyanobacteria. South African Journal of Botany. 75: 466474.

\section{How to cite this article:}

Himani Priya, Kumari Chanchala Priya, Neeraj Kumar, Ranjit Singh and Dolly Wattal Dhar. 2018. Influence of Low pH Stress on Growth, Specific Biochemical Parameters and Antioxidants amongst Selected Nostoc Strains. Int.J.Curr.Microbiol.App.Sci. 7(07): 3055-3064. doi: https://doi.org/10.20546/ijcmas.2018.707.356 